\title{
Effects of Nocturnal Soil Temperatures and Meloidogyne incognita Densities on Cotton Seedling Growth and the Interaction with Thielaviopsis basicola
}

\author{
W. S. Monfort, Graduate Student, Department of Plant Pathology, The University of Arkansas, Fayetteville 72701; \\ T. L. Kirkpatrick, Professor, Department of Plant Pathology, The Southwest Research and Extension Center, Hope, \\ AR 71801; and C. S. Rothrock, Professor, Department of Plant Pathology, The University of Arkansas, Fayetteville \\ 72701
}

\begin{abstract}
Monfort, W. S., Kirkpatrick, T. L., and Rothrock, C. S. 2006. Effects of nocturnal soil temperatures and Meloidogyne incognita densities on cotton seedling growth and the interaction with Thielaviopsis basicola. Plant Dis. 90:519-522.

Controlled studies were conducted to evaluate the effects of soil temperatures typical of field conditions during the first 6 weeks of the growing season in Arkansas and different population densities of Meloidogyne incognita on damage to cotton (Gossypium hirsutum) seedlings associated with the interaction between $M$. incognita and Thielaviopsis basicola. Treatments consisted of varying nocturnal temperatures that approximated the temperatures that occurred during the 2001, 2002, and 2003 growing seasons in southeastern Arkansas. Nocturnal temperatures in the study were as follows: high, the first week at $15^{\circ} \mathrm{C}$, followed by 3 weeks at $17^{\circ} \mathrm{C}, 1$ week at $21^{\circ} \mathrm{C}$, and 1 week at $17^{\circ} \mathrm{C}$ (approximating the 2002 season); medium, 3 weeks at $15^{\circ} \mathrm{C}$ and 3 weeks at $19^{\circ} \mathrm{C}$ (approximating the 2003 season); and low, 1 week at $15^{\circ} \mathrm{C}, 1$ week at $13^{\circ} \mathrm{C}, 2$ weeks at $17^{\circ} \mathrm{C}, 1$ week at $15^{\circ} \mathrm{C}$, and 1 week at $17^{\circ} \mathrm{C}$ (approximating the 2001 season). Pathogen population densities were either 0 or 100 chlamydospores of $T$. basicola per gram of soil and 0 , 2,000, 4,000, or 8,000 eggs of $M$. incognita per $500 \mathrm{~cm}^{3}$ of soil. Plant height and fresh top weight increased with an increase in nocturnal temperature across treatments. There were significant reductions in plant growth and development with $T$. basicola, but not with $M$. incognita, at these nocturnal temperatures, but decreased plant height and weight were seen where both pathogens were present in comparison with either pathogen alone. Trends of increased disease associated with $T$. basicola were observed with increasing inoculum rates of $M$. incognita, indicating that the interaction between $T$. basicola and $M$. incognita occurs even at soil temperatures below the minimum temperature reported as necessary for damage from $M$. incognita.
\end{abstract}

Additional keywords: black root rot, nematode-fungal interaction, root-knot nematode

Cotton producers in Arkansas lost an estimated \$124 million in 2004 from diseases (1). Two important pathogens of cotton (Gossypium hirsutum L.) in Arkansas are the root-knot nematode (Meloidogyne incognita (Kofoid \&White) Chitwood) and Thielaviopsis basicola (Berk. \& Broome) Ferris (syn. Chalara elegans Nag Raj \& Kendrick). Both pathogens are widely distributed and can cause significant damage. Walker et al. (12) demonstrated a synergistic interaction between M. incognita and T. basicola in cotton. A significant increase in seedling death and a decrease in plant growth and yield occurred in microplots infested with both $T$. basicola and $M$. incognita compared with microplots infested with either pathogen alone (12). Histological observations suggested that infection of cotton roots by the

Corresponding author: T. L. Kirkpatrick

E-mail: tkirkpatrick@uaex.edu

Accepted for publication 6 December 2005.

DOI: 10.1094/PD-90-0519

(C) 2006 The American Phytopathological Society nematode allows $T$. basicola to colonize vascular tissues that are not normally colonized in the absence of the nematode (11).

The interaction between these pathogens also was found to alter their epidemiology. Co-infection of cotton by both $T$. basicola and $M$. incognita appeared to alter the effective range at which the pathogens cause damage (10). Although plant damage was increased by this association, population densities of $M$. incognita were suppressed as early as $\mathbf{5 7}$ days after planting in this study.

Currently, the only viable option to limit the damage associated with the interaction between T. basicola and M. incognita is to control the nematode using nematicides, but the costs of these materials, the need for specialized application equipment, and human and environmental risks associated with their use have discouraged many growers from routinely using nematicides. Unfortunately, the lack of routine nematicide use and cotton monoculture have created an environment where disease incidence and severity are extremely high. Historically, many producers have relied on cultural practices including planting date, irrigation management, and optimiz- ing soil fertility to maximize plant growth and mitigate losses from this interaction. Little data is available concerning the environmental and edaphic factors involved in the initiation of the interaction between these organisms under normal growing conditions. The objective of this study was to evaluate the effects of soil temperatures representative of the first 6 weeks of the growing season in southeastern Arkansas on each pathogen alone and on the interaction between them. A second objective was to determine the effect of increasing $M$. incognita population densities on the severity of the seedling damage associated with this interaction.

\section{MATERIALS AND METHODS}

Trials were conducted in environmentally controlled growth chambers (Conviron, Pembina, ND) at the University of Arkansas, Fayetteville. A Rilla silt loam soil (40\% sand, $56 \%$ silt, and $4 \%$ clay) from a field known to be infested with both organisms and with a history of severe disease problems was utilized in this study. The soil was steam pasteurized for $0.5 \mathrm{~h}$ at $70^{\circ} \mathrm{C}$ to eliminate potential cotton pathogens and then reinfested with either $M$. incognita, T. basicola, or both organisms. For inoculum, chlamydospore chains of $T$. basicola were harvested from cultures on $10 \%$ carrot juice agar and digested with chitinase to obtain single spores (2). Chlamydospore germinability was assessed after $24 \mathrm{~h}$ on carrot juice agar, and inoculum rates were calculated as the number of viable chlamydospores per gram of oven-dried soil. $M$. incognita was collected from an infested field in Drew County, AR, and increased on tomato ( $L y$ copersicon esculentum L.) cv. Rutgers in a greenhouse at the University of Arkansas Southwest Research and Extension Center (SWREC) at Hope. Nematode eggs were extracted from infected tomato roots using $0.05 \% \mathrm{NaOCl}$ for $2 \mathrm{~min}$ as described by Hussey and Barker (5). Nematode population densities were calculated as the number of nematode eggs per $500 \mathrm{~cm}^{3}$ of soil. Treatments studied in this experiment were: (i) uninfested control; (ii) $M$. incognita, 4,000 eggs per $500 \mathrm{~cm}^{3}$ of soil; (iii) $T$. basicola, 100 chlamydospores per $\mathrm{g}$ of soil; (iv) M. incognita, 2,000 eggs per 500 $\mathrm{cm}^{3}$ of soil and T. basicola, 100 chlamydospores per g of soil; (v) M. incognita, 
4,000 eggs per $500 \mathrm{~cm}^{3}$ of soil and T. basicola, 100 chlamydospores per $\mathrm{g}$ of soil; and (vi) M. incognita, 8,000 eggs per 500 $\mathrm{cm}^{3}$ of soil and T. basicola, 100 chlamydospores per $\mathrm{g}$ of soil. The level of T. basicola (100 chlamydospores per g) that was chosen for this test was based on previous research that showed that this level was adequate to cause severe disease (11). Three seeds of the cotton cultivar DP 451 B/RR (Delta and Pine Land Company, Scott, MS) were planted into $10.2-\mathrm{cm}-$ diameter clay pots with soil infested with the appropriate pathogen treatments. After emergence, plant populations were thinned to two plants per pot.

All treatments were subjected to three nocturnal temperature regimes representing typical field conditions in the first 6 weeks of the growing season. Each temperature regime was based on extrapolation from environmental soil temperature data collected at the Southeast Research and Extension Center, Rohwer Division, Rohwer, AR, from a weather monitoring station during the spring of 2001, 2002, and 2003. Although the recorded soil temperatures fluctuated throughout both the daytime and night hours, the nocturnal soil temperatures had the greatest differences among years. Therefore, the pattern of nocturnal soil temperatures each of the 3 years was approximated as a treatment (Fig. 1). A diurnal regime of $14 \mathrm{~h}$ daylight with a light intensity of 400 micromoles $/ \mathrm{m}^{2} / \mathrm{s}$ and $10 \mathrm{~h}$ darkness was used.
Daytime soil temperatures remained constant for all three temperature regimes at $24^{\circ} \mathrm{C}$ for the first 3 weeks and $26^{\circ} \mathrm{C}$ for the last 3 weeks of the study. The nocturnal temperature regimes were as follows: high ( 1 week at $15^{\circ} \mathrm{C}, 3$ weeks at $17^{\circ} \mathrm{C}, 1$ week at $21^{\circ} \mathrm{C}$, and 1 week at $17^{\circ} \mathrm{C}$ ), which approximated conditions in 2002; medium (3 weeks at $15^{\circ} \mathrm{C}$ and 3 weeks at $19^{\circ} \mathrm{C}$ ), which approximated conditions in 2003; and low $\left(1\right.$ week at $15^{\circ} \mathrm{C}, 1$ week at $13^{\circ} \mathrm{C}$, 2 weeks at $17^{\circ} \mathrm{C}, 1$ week at $15^{\circ} \mathrm{C}$, and 1 week at $17^{\circ} \mathrm{C}$ ), which approximated the 2001 soil temperature fluctuations.

Six replications of each pathogentemperature combination were used, and treatments were randomized within each growth chamber. The duration of the experiment was 42 days. The experiment was repeated (three separate runs) during the period from December 2003 to November 2004. Pots were watered from above at 2day intervals. At the conclusion of an experiment, plant height from the cotyledonary node to the apex of the terminal bud and the number of main stem nodes were recorded. Plants were extracted from the pots, roots were rinsed, and aboveground (FTW) and root (FRW) weights were recorded. Roots were rated for root discoloration based on the percentage ( 0 to $100 \%$ ) of the root system discolored, and for galling due to $M$. incognita based on the scale: $0=$ no galling visible, $1=1$ to $10 \%$ of roots galled, $2=11$ to $25 \%$ galled, $3=26$ to $50 \%$ galled, $4=51$ to $75 \%$

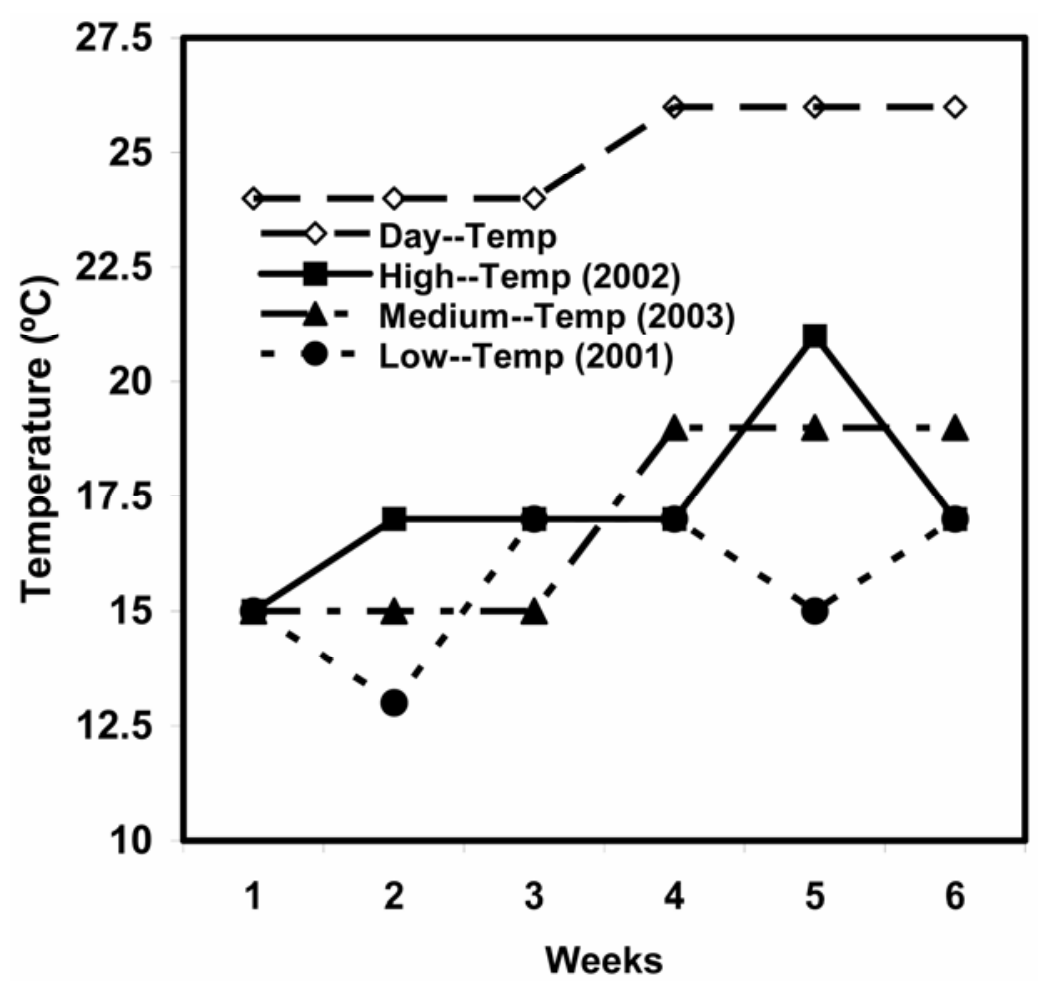

Fig. 1. Weekly nocturnal temperature regimes for evaluation of the effects of soil temperature and Meloidogyne incognita populations on the interaction of M. incognita and Thielaviopsis basicola on cotton. Nocturnal temperature regimes were extrapolated from recorded environmental soil temperatures at the Southeast Research and Extension Center, Rohwer Division, Rohwer, AR. All nocturnal temperature regimes had the same daytime temperatures throughout the 6-week study. galled, and $5=>75 \%$ galled. After roots were rated for percent discoloration and root galling, roots were rinsed for $20 \mathrm{~min}$ with water, surface-disinfested with $0.5 \%$ $\mathrm{NaOCl}$ for $1.5 \mathrm{~min}$, and blotted dry. The entire root system was then plated on the $T$. basicola selective medium TB-CEN (8) that was amended with Penicillin G (60 $\mathrm{mg} /$ liter) (Sigma-Aldrich, Inc., St. Louis, MO). Roots were observed after 14 days on TB-CEN and rated for T. basicola colonization based on the percentage ( 0 to $100 \%$ ) of the root system having T. basicola growing onto the medium.

Data were analyzed as a split-plot experimental design with temperature as the main effect and pathogen treatments as the subplot. Statistical analyses were conducted with SAS (SAS Institute, Cary, NC) to evaluate the effects of varying environmental temperature regimes and inoculum rates of $M$. incognita with and without $T$. basicola on plant development and disease severity. Treatment means were compared with Fisher's protected least significant difference (LSD) at $P \leq 0.05$. For root galling, mid-percentile values for each gall rating were used for analyses. $M$. incognita controls were omitted in analysis of percent discoloration and percent colonization, and the T. basicola control was omitted from the root galling analyses. Data are presented from the combined analyses of the three experiments.

\section{RESULTS}

There were significant run $\times$ temperature, run $\times$ pathogen treatment, and run $\times$ temperature $x$ pathogen treatment interactions (Table 1). Significant run $\times$ treatment interactions were due to magnitude effects among runs. Therefore, the run interactions with temperature and pathogen treatments were treated as random effects (random error) for the fixed effects in the statistical analyses. The temperature $x$ pathogen treatment interaction was tested using the run $\times$ temperature $\times$ pathogen treatment interaction as the error term. The error utilized for temperature and pathogen treatments were $\mathrm{e}=$ run $\times$ temperature and $\mathrm{e}=$ run $\times$ pathogen treatment, respectively.

There was no temperature $\times$ pathogen treatment interaction for any of the growth parameters; therefore, the data were pooled by main effect (Table 1). The growth and development of the cotton seedlings was greatest in the high (warmest) nocturnal temperature regime. Plant height was greater for the high temperature regime than for the medium temperature regime and was numerically greater than with the low temperature regime. There was a significant increase in FTW for the highest temperature regime compared with the other temperature regimes (Table 2). A numerical increase in the FRW and plant nodes also was observed in the highest temperature compared with the other two 
temperature regimes; however, the differences were not significant (Table 2).

The pathogens had a significant effect on growth and development of the seedlings across all temperature regimes. Plant height was lower $(P=0.05)$ in all pathogen treatments except for the $M$. incognita control than in the nontreated control (Table 2). Plant height was reduced in T. basicola treatments with 4,000 or more eggs of M. incognita per $500 \mathrm{~cm}^{3}$ of soil than with T. basicola alone (Table 2). The number of main stem nodes was numerically lower with $M$. incognita, and a significant $(P=$ $0.05)$ reduction in the number of nodes was observed in both the treatment with $T$. basicola alone and in all treatments with both pathogens. As was seen in plant height, the number of nodes for the T. $b a$ sicola treatments with 4,000 or more eggs of $M$. incognita per $500 \mathrm{~cm}^{3}$ of soil was lower $(P=0.05)$ than with $T$. basicola alone (Table 2). FTW and FRW were suppressed by $T$. basicola alone, and both FTW and FRW were lower in T. basicola treatments that included $M$. incognita infestation rates of 4,000 and 8,000 eggs per $500 \mathrm{~cm}^{3}$ of soil than with either pathogen alone (Table 2). Across all growth parameters, there was a trend toward reduced plant growth and development due to the interaction between $T$. basicola and $M$. incognita with increasing inoculum rates of $M$. incognita.

There was no observed temperature $x$ pathogen treatment interaction for percent discoloration or percent colonization. Trends toward increased discoloration and colonization by $T$. basicola were observed in the cooler temperature regimes compared with the warmest nocturnal temperature regime. Percent root colonization was greater $(P=0.05)$ at the lowest nocturnal temperature regime than in the highest nocturnal temperature regime. There also was a trend toward increased discoloration and root colonization from $T$. basicola with $M$. incognita also present than with $T$. basicola alone, although the increase was not significant (Table 3 ).

Root galling was numerically greater at the warmest temperature regime where mean root galling was 3.0, 2.7, and 2.6 in the high, medium, and low nocturnal temperature regimes, respectively, for the $M$. incognita alone treatments. Root galling was lower $(P=0.05)$ in all treatments that included $T$. basicola compared with treatments with $M$. incognita alone (Table 3).

\section{DISCUSSION}

Since the interaction between $T$. basicola and M. incognita was demonstrated in 1998 on cotton in Arkansas by Walker et al. (12), research has focused mainly on characterizing the interaction and the damage that is caused to cotton seedlings at optimal temperatures for the host. However, optimum environmental temperatures for T. basicola and M. incognita are quite different. Rothrock (7) found that damage associated with $T$. basicola colonization was higher at temperatures between 20 and $24^{\circ} \mathrm{C}$ than at $28^{\circ} \mathrm{C}$. Damage associated with $M$. incognita infection was found to be greatest in soils at temperatures between 25 and $30^{\circ} \mathrm{C}(3,4)$. Severe black root rot of cotton has generally been associated with seasons characterized by cooler soil temperatures (T. L. Kirkpatrick, unpublished), while severe $M$. incognita damage is more often associated with warmer temperatures (3). Based on the study by Walker et al. (12), the soil temperatures at which damage associated with both $T$. basicola and $M$. incognita occurred ranged from 20 to $30^{\circ} \mathrm{C}$. Along with extended temperature ranges for damage associated with the two pathogens, they found that the combined effect of the two pathogens was greater than the effect of either pathogen alone over these temperatures.

Little information is available on the effects of the interaction at fluctuating soil temperatures that are more typical of actual field conditions. In years where the disease is severe, the seedling damage associated with the interaction of T. basicola and $M$. incognita is evident within the first 6 weeks of the growing season (9). During the period of 2001 to 2003, soil temperatures during the first 6 weeks after planting ranged from 13 to $18^{\circ} \mathrm{C}$ at night and 22 to $26^{\circ} \mathrm{C}$ during the day (Southeast Research and Extension Center, Rohwer Division). Based on previous research, $M$. incognita infection and reproduction is greatly reduced at temperatures below $18^{\circ} \mathrm{C}(6)$, suggesting that damage from $M$. incognita was likely minimal during this

Table 2. The effect of Meloidogyne incognita (Mi) and Thielaviopsis basicola (Tb) on cotton plant growth and development 42 days after planting

\begin{tabular}{lclll}
\hline Main effects & $\begin{array}{c}\text { Plant height } \\
(\mathbf{c m})\end{array}$ & $\begin{array}{c}\text { Plant } \\
\text { nodes }\end{array}$ & $\begin{array}{c}\text { Fresh top } \\
\text { weight }(\mathbf{g})\end{array}$ & $\begin{array}{c}\text { Fresh root } \\
\text { weight }(\mathbf{g})\end{array}$ \\
\hline $\begin{array}{l}\text { Nocturnal temperature } \\
\text { High }\end{array}$ & $34.10 \mathrm{~A}^{\mathrm{x}}$ & $2.60 \mathrm{~A}$ & $4.33 \mathrm{~A}$ & $1.24 \mathrm{~A}$ \\
$\quad$ & $24.90 \mathrm{~B}$ & $2.10 \mathrm{~A}$ & $2.70 \mathrm{~B}$ & $1.04 \mathrm{~A}$ \\
$\quad$ Medium & $28.19 \mathrm{AB}$ & $2.10 \mathrm{~A}$ & $3.09 \mathrm{~B}$ & $0.84 \mathrm{~A}$ \\
$\quad$ Low & & & & \\
Pathogen & $38.06 \mathrm{~A}$ & $3.03 \mathrm{~A}$ & $5.38 \mathrm{~A}$ & $1.65 \mathrm{~A}$ \\
$\quad$ Non-treated control & $35.89 \mathrm{AB}$ & $2.83 \mathrm{AB}$ & $4.46 \mathrm{AB}$ & $1.71 \mathrm{~A}$ \\
$4,000^{\mathrm{y}} \mathrm{Mi}$ & $30.89 \mathrm{BC}$ & $2.40 \mathrm{BC}$ & $3.77 \mathrm{BC}$ & $1.11 \mathrm{~B}$ \\
$100^{\mathrm{z}} \mathrm{Tb}$ & $26.57 \mathrm{CD}$ & $2.08 \mathrm{CD}$ & $2.75 \mathrm{CD}$ & $0.74 \mathrm{BC}$ \\
$2,000 \mathrm{Mi}+100 \mathrm{~Tb}$ & $22.96 \mathrm{D}$ & $1.87 \mathrm{DE}$ & $2.28 \mathrm{D}$ & $0.60 \mathrm{BC}$ \\
$4,000 \mathrm{Mi}+100 \mathrm{~Tb}$ & $21.21 \mathrm{D}$ & $1.57 \mathrm{E}$ & $1.84 \mathrm{D}$ & $0.50 \mathrm{C}$ \\
$8,000 \mathrm{Mi}+100 \mathrm{~Tb}$ & &
\end{tabular}

${ }^{\text {w }} \mathrm{High}=1$ week at $15^{\circ} \mathrm{C}, 3$ weeks at $17^{\circ} \mathrm{C}, 1$ week at $21^{\circ} \mathrm{C}$, and 1 week at $17^{\circ} \mathrm{C}$; medium $=3$ weeks at $15^{\circ} \mathrm{C}$ and 3 weeks at $19^{\circ} \mathrm{C}$; low $=1$ week at $15^{\circ} \mathrm{C}, 1$ week at $13^{\circ} \mathrm{C}, 2$ weeks at $17^{\circ} \mathrm{C}, 1$ week at $15^{\circ} \mathrm{C}$, and 1 week at $17^{\circ} \mathrm{C}$.

${ }^{x}$ Treatment values with the same letter within a column and main effect do not differ significantly, protected LSD $P \leq 0.05$.

${ }^{y}$ Eggs per $500 \mathrm{~cm}^{3}$ of soil.

${ }^{\mathrm{z}}$ CFU per gram of soil.

Table 1. Main and interaction effects ( $P$ values) for cotton grown in soil infested with Meloidogyne incognita $(\mathrm{Mi})$ and Thielaviopsis basicola $(\mathrm{Tb})^{\mathrm{x}}$ in controlled environmental growth chambers for 42 days

\begin{tabular}{|c|c|c|c|c|c|c|c|c|}
\hline Source & df & $\begin{array}{c}\text { Height } \\
\text { (cm) }\end{array}$ & Nodes & $\begin{array}{l}\text { Fresh top } \\
\text { weight (g) }\end{array}$ & $\begin{array}{l}\text { Fresh root } \\
\text { weight (g) }\end{array}$ & $\begin{array}{c}\text { Discoloration } \\
(\%)^{\mathrm{y}}\end{array}$ & $\begin{array}{c}\text { Colonization } \\
(\%)^{\mathrm{y}}\end{array}$ & $\begin{array}{c}\text { Root gall } \\
\text { index }\end{array}$ \\
\hline Run & 2 & 0.0002 & 0.0032 & 0.0220 & 0.0374 & 0.1530 & 0.0285 & 0.0130 \\
\hline Temperature & 2 & 0.0249 & 0.1432 & 0.0197 & 0.0159 & 0.2114 & 0.0725 & 0.0832 \\
\hline Run $\times$ temperature & 4 & 0.0027 & 0.0072 & 0.0183 & 0.0116 & 0.1529 & 0.1027 & 0.2903 \\
\hline Treatment & 5 & 0.0007 & 0.0004 & 0.0011 & 0.0019 & 0.0001 & 0.0662 & 0.0002 \\
\hline Run $\times$ treatment & 10 & 0.0043 & 0.0980 & 0.0018 & 0.0033 & 0.2886 & 0.0001 & 0.0011 \\
\hline Temp $\times$ treatment & 10 & 0.1321 & 0.8334 & 0.0782 & 0.2336 & 0.3245 & 0.1443 & 0.5249 \\
\hline Run $\times$ temperature $\times$ treatment & 20 & 0.2138 & 0.0018 & 0.3430 & 0.0513 & 0.0010 & 0.0902 & 0.0001 \\
\hline
\end{tabular}

${ }^{x}$ Analysis based on three runs and six replications per run.

${ }^{y}$ Root discoloration and colonization based on a 0 to $100 \%$ scale of root system discolored and colonized by $T$. basicola when placed on the selective media TB-CEN

${ }^{\mathrm{z}}$ Root galling index based on a scale of 0 to 5 , where $0=$ no galling visible, $1=1$ to $10 \%$ of roots galled, $2=11$ to $25 \%$ galled, $3=26$ to $50 \%$ galled, $4=51$ to $75 \%$ galled, and $5=>75 \%$ galled. 
Table 3. The effect of Meloidogyne incognita (Mi) and Thielaviopsis basicola $(\mathrm{Tb})$ on disease on cotton 42 days after planting

\begin{tabular}{|c|c|c|c|}
\hline Main effects & $\begin{array}{c}\text { Root discoloration } \\
(\%)^{t}\end{array}$ & $\begin{array}{c}\text { Root colonization } \\
(\%)^{t}\end{array}$ & $\begin{array}{l}\text { Root gall index } \\
\qquad\left(0-5^{\mathbf{u}}\right)\end{array}$ \\
\hline \multicolumn{4}{|l|}{ Nocturnal temperature ${ }^{\mathrm{v}}$} \\
\hline High & $18.30 \mathrm{~A}^{\mathrm{w}}$ & $21.10 \mathrm{~B}$ & $1.46 \mathrm{~A}$ \\
\hline Medium & $26.20 \mathrm{~A}$ & $26.80 \mathrm{AB}$ & $1.10 \mathrm{~A}$ \\
\hline Low & $24.40 \mathrm{~A}$ & $33.40 \mathrm{~A}$ & $1.11 \mathrm{~A}$ \\
\hline \multicolumn{4}{|l|}{ Pathogen } \\
\hline $4000^{x} \mathrm{Mi}$ & $\mathrm{NI}^{\mathrm{y}}$ & NI & $2.80 \mathrm{~A}$ \\
\hline $100^{\mathrm{z}} \mathrm{Tb}$ & $26.40 \mathrm{~A}$ & $19.96 \mathrm{~A}$ & NI \\
\hline $2000 \mathrm{Mi}+100 \mathrm{~Tb}$ & $26.50 \mathrm{~A}$ & $34.77 \mathrm{~A}$ & $0.99 \mathrm{~B}$ \\
\hline $4000 \mathrm{Mi}+100 \mathrm{~Tb}$ & $31.25 \mathrm{~A}$ & $44.83 \mathrm{~A}$ & $1.10 \mathrm{~B}$ \\
\hline $8000 \mathrm{Mi}+100 \mathrm{~Tb}$ & $29.13 \mathrm{~A}$ & $35.09 \mathrm{~A}$ & $1.15 \mathrm{~B}$ \\
\hline
\end{tabular}

${ }^{\mathrm{t}}$ Root discoloration and colonization based on a 0 to $100 \%$ scale of root system discolored and colonized by $T$. basicola when placed on the selective media TB-CEN.

u Root galling index based on a scale of 0 to 5 , where $0=$ no galling visible, $1=1$ to $10 \%$ of roots galled, $2=11$ to $25 \%$ galled, $3=26$ to $50 \%$ galled, $4=51$ to $75 \%$ galled, and $5=>75 \%$ galled

${ }^{\mathrm{v}} \mathrm{High}=1$ week at $15^{\circ} \mathrm{C}, 3$ weeks at $17^{\circ} \mathrm{C}, 1$ week at $21^{\circ} \mathrm{C}$, and 1 week at $17^{\circ} \mathrm{C}$; medium $=3$ weeks at $15^{\circ} \mathrm{C}$ and 3 weeks at $19^{\circ} \mathrm{C}$; low $=1$ week at $15^{\circ} \mathrm{C}, 1$ week at $13^{\circ} \mathrm{C}, 2$ weeks at $17^{\circ} \mathrm{C}, 1$ week at $15^{\circ} \mathrm{C}$, and 1 week at $17^{\circ} \mathrm{C}$.

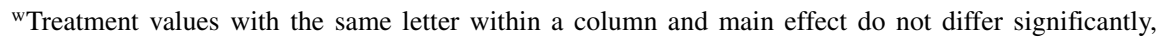
protected LSD $P \leq 0.05$.

${ }^{\mathrm{x}}$ Eggs per $500 \mathrm{~cm}^{3}$ of soil.

y Treatment not included (NI) in statistical analysis.

${ }^{\mathrm{z}} \mathrm{CFU}$ per gram of soil.

period. This is supported in our study by the fact that the treatment that included the nematode alone did not affect plant growth or development even though some root galling was observed. Seedlings were, however, damaged by $T$. basicola at these temperatures. Soil temperature and the presence of both pathogens significantly affected both plant development and disease. Plant growth, measured both as development and weight, increased with an increase in nocturnal temperature across treatments, but plant development was adversely affected by $T$. basicola and $M$. incognita, with the highest level of damage observed in soils as $M$. incognita inoculum increased.

Disease severity associated with infection by $T$. basicola and $M$. incognita was influenced both by changes in nocturnal temperature regimes and by the population level of the nematode. The highest levels of discoloration and colonization were observed in the low and medium temperature regimes, suggesting that $T$. basicola causes greater damage at temperatures ranging from 13 to $19^{\circ} \mathrm{C}$ than from 15 to $21^{\circ} \mathrm{C}$. The trend toward increased root discoloration and colonization by $T$. basicola with increasing populations of $M$. incognita is likely an indication that $M$. incognita is interacting with $T$. basicola at temperatures well below the optimum temperature for the nematode. Root galling caused by $M$. incognita was suppressed in all of the T. basicola treatments that included $M$. incognita, which is in agreement with previous research (11).

The interaction between $T$. basicola and $M$. incognita is a significant factor in seedling establishment and growth in Arkansas cotton fields. It occurs across a range of soil temperatures that are common in the region, and is most severe in fields with $M$. incognita infestation even though the nematode is not considered to be a cropdamaging factor at these temperatures. This study indicates that the early growth and development of the plant may play a role in the severity of the interaction. Plants in the cooler temperature regimes were limited in both growth and development in the absence of the pathogens. It is likely, therefore, that the impact of this interaction on the crop would be greatest in seasons with cooler temperatures. In addition, black root rot would likely be most severe where root-knot nematodes are also present, even in environments in which the nematode has not traditionally been considered to be damaging, and the severity of the interaction will be greater with increasing population densities of $M$. incognita.

\section{ACKNOWLEDGMENTS}

Published with the approval of the Director, Arkansas Experiment Station, Fayetteville. We thank R. W. McNew, Agricultural Statistics Laboratory, University of Arkansas, Fayetteville, for his assistance with the statistical analyses for this research project.

\section{LITERATURE CITED}

1. Blasingame, D. C., and Patel, M. V. 2005 Cotton disease loss estimate committee report. Pages 259-263 in: 2005 Proc. Beltwide Cotton Conf. P. Dugger and D. Richter, eds. National Cotton Council of America, Memphis, TN.

2. Candole, B. L., and Rothrock, C. S. 1997. Characterization of the suppressiveness of hairy vetch-amended soils to Thielaviopsis basicola. Phytopathology 87:197-202.

3. Carter, W. W. 1975. Effects of soil temperatures and inoculum levels of Meloidogyne incognita and Rhizoctonia solani on seedling disease of cotton. J. Nematol. 7:229-233.

4. Goodell, P. B., and Ferris, H. 1989. Influence of environmental factors on the hatch and survival of Meloidogne incognita. J. Nematol 21:328-334

5. Hussey, R. S., and Barker, K. R. 1973. A comparison of methods of collecting inocula of Meloidogyne spp., including a new technique. Plant Dis. Rep. 57:1025-1028.

6. Roberts, P. A., Van Gundy, S. D., and McKinney, H. E. 1981. Effects of soil temperature and planting of wheat on Meloidogyne incognita reproduction, soil populations and grain yield. J. Nematol. 13:338-344

7. Rothrock, C. S. 1992. Influence of soil temperature, water, and texture on Thielaviopsis basicola and black root rot of cotton. Phytopathology 82:1202-1206.

8. Specht, L. P., and Griffin, G. J. 1985. A selective medium for enumerating low populations of Thielaviopsis basicola in tobacco field soils. Can. J. Plant Pathol. 7:438-441.

9. Starr, J. L., Wheeler, T. A., and Walker, N. R. 2001. Nematode-fungal interactions. Pages $46-$ 47 in: Compendium of Cotton Diseases. 2nd ed. T. L. Kirkpatrick and C. S. Rothrock, eds. American Phytopathological Society, St. Paul, $\mathrm{MN}$.

10. Walker, N. R. 1998. Interaction between Meloidogyne incognita and Thielaviopsis basicola on cotton (Gossypium hirsutum). J. Nematol. 30:415-422.

11. Walker, N. R., Kirkpatrick, T. L., and Rothrock, C. S. 1999. Effect of temperature on and histopathology of the interaction between Meloidogyne incognita and Thielaviopsis basicola on cotton. Phytopathology 89:613-617.

12. Walker, N. R., Kirkpatrick, T. L., and Rothrock, C. S. 2000. Influence of Meloidogyne incognita and Thielaviopsis basicola populations on early-season disease development and cotton growth. Plant Dis. 84:449453. 